\title{
Pareceristas - Ano VI, Número 11, junho - dezembro de 2017
}

\section{(2) OpenEdition \\ Journals}

Electronic version

URL: http://journals.openedition.org/espacoeconomia/3086

DOI: 10.4000/espacoeconomia.3086

ISSN: 2317-7837

Publisher

Núcleo de Pesquisa Espaço \& Economia

\section{Electronic reference}

«Pareceristas - Ano VI, Número 11, junho - dezembro de 2017 », Espaço e Economia [Online], 11 | 2017, Online since 06 April 2018, connection on 24 September 2020. URL : http://

journals.openedition.org/espacoeconomia/3086 ; DOI : https://doi.org/10.4000/espacoeconomia. 3086

This text was automatically generated on 24 September 2020.

(c) NUPEE 


\title{
Pareceristas - Ano VI, Número 11, junho - dezembro de 2017
}

\author{
Agradecemos a contribuição generosa dos seguintes pareceristas: \\ André Santos da Rocha (UFRRJ) \\ Désirée Guichard Freire (UERJ) \\ Denise Rissato (UNIOESTE/PR) \\ Eveline Bertino Algebaile (UERJ) \\ Gaudêncio Frigoto (UERJ) \\ Jorge Luiz Barbosa (UFF) \\ Leandro Dias de Oliveira (UFRRJ) \\ 9 Nelson Laura Mabucanhane (ISAP-Mabuto-Mocambique) \\ 10 Roberto Alves de Arruda (UNEMAT) \\ 11 Roberto da Cruz Mello (IFBA) \\ 12 Romeu e Silva Neto (IFF-Campos dos Goytacazes)
}

